\title{
Populations of Heracleum sosnowskyi and H. mantegazzianum (Apiaceae) in Kyiv (Ukraine)
}

\author{
Lubov Gubar, Serhii Koniakin* \\ Institute for Evolutionary Ecology, National Academy of Sciences of Ukraine, \\ 03143, Kyiv, 37 Lebedeva st., Ukraine
}

\begin{abstract}
Gubar, L., Koniakin, S., 2021. Populations of Heracleum sosnowskyi and H. mantegazzianum (Apiaceae) in Kyiv (Ukraine). Folia Oecologica, 48 (2): 215-228.

In connection with the increasing negative impact of invasive alien species on biodiversity and the environment in general, their research, as well as throughout the world, is relevant. The distribution of the Heracleum sosnowskyi and $H$. mantegazzianum of the secondary range on the example of the Kyiv agglomeration is investigated in the work. In our study we aimed to evaluate the possibility of spontaneous spread of giant hogweeds in the secondary range, adaptation of the species to the new conditions of the environment that favor to control of these species' expansion and reduce the threat to the urban ecosystems and citizens' health. We hypothesise that in the secondary range $H$. sosnowskyi and $H$. mantegazzianum settle sites with relatively high temperature (Tr), lightening (Lc), and soil moisture conditions similar to that in their natural range. 17 populations and four localities (sites) of $H$. sosnowskyi and H. mantegazzianum were studied. They were found within forest, meadow, riverine and ruderal plant communities. It is indicated that the advent species fully adapted to the conditions of the environment. The difference by ecological indicators Lc2 and Tm1 is pointed out. According to the results of our research, for the area of Kyiv urban agglomeration the growth of $H$. sosnowskyi and $H$. mantegazzianum is indicated in the plants communities of six classes. They spread most in ruderal plant communities of the: Robinietea, Artemisietea, Epilobietea classes. The studied species belong to invasive plant species in Ukraine and are characterized by extremely high effect on the environment and high invasive potential.
\end{abstract}

\section{Keywords}

giant hogweeds, invasive alien species, Kyiv, populations

\section{Introduction}

During the recent decades in the world the negative effect of the alien plant species on the environment has increased due to the transformation of natural ecosystems by a man, particularly the regulation of reservoirs, largescale deforestation, recreational load, artificial drainage and flooding of the territories, and, also, climate change (McNeely et al., 2001; Stukalyuk et al., 2019; RaI and SINGH, 2020). This issue has been of great importance as the invasion of alien plant species causes irreparable damage to the existence of the aboriginal species and normal function of the ecosystems. The fight with the most dangerous alien plant species, according to the data of the Global Invasive Species Programme (GISP), costs mankind 1.4 trillion dollars annually. The modern world practice considers the problem of the biological invasions to be one of the greatest threats to the biotic diversity (REASER et al., 2003; Biological invasions: a growing threat to biodiversity, human health and food security, 2012; European Strategy on Invasive

\footnotetext{
*Corresponding author: e-mail: ser681@ukr.net 
Alien Species, 2015; European Commission, 2017). Over the past 20-30 years the rapid spread and active invasive potential of Heracleum sosnowskyi and H. mantegazzianum (Apiaceae) have been recorded all over the world (LAMDON et al., 2008; Centre for Agriculture and Biosciences International (CABI), 2019).

Now, the alien range of Sosnowski's hogweed (Heracleum sosnowskyi) recognized as invasive in a number of countries: the Baltic States (BALEZENTIENE et al., 2013; MeZaKa et al., 2016), Republic of Belarus (LAman et al., 2009), Ukraine (VYKHOR and PROTS, 2012), European part of Russia (PANASENKo, 2017; Arepieva et al., 2021), sporadically occurring Poland (KLima and SynOwIEC, 2016), Hungary (KabuCE and Priede, 2010) and Denmark (JAHOdoví et al., 2007). In a number of countries Sosnowski's hogweed received the status of invasive and was not officially registered at the state level, particularly in Denmark, Serbia, Bulgaria (Vladimirov et al., 2019), Georgia, Armenia, Azerbaijan, Turkey, the Russian Federation (Centre for Agriculture and Biosciences International (CABI), 2019).

The Giant hogweed (Heracleum mantegazzianum) is recognized as invasive in a number of countries: the USA (CASE and BeAmon, 1992), Canada (PAge et al., 2006), and European countries: Hungary (CsiszÁr et al., 2020); Slovakia (FeHÉR, 2000; PAuKová et al., 2019); Germany (RAJMis et al., 2016); Czech Republic (Moravcová et al., 2018); Denmark (ANDERSEN and CAlov, 1996); Ireland (CAFFrEY, 1999) and other countries. In a number of countries hogweed received the status of invasive and was not officially registered at the state level, particularly in Australia, New Zealand, Turkey, Iran, Georgia, the Russian Federation, Ukraine, the Republic of Poland, Greece, Iceland, Latvia, Slovenia, Bosnia and Herzegovina (Maslo, 2010; Centre for Agriculture ..., 2019).

In Central Europe, Heracleum species had been as decorative plants since 1890 (MANDENOVA, 1950). However, quite rapidly the two properties were manifested, that limiting their cultivation: frequent cases of dermatitis, and a fast spread by self-seeding and vegetatively beyond the measures of cultivation (SAZYPEROVA, 1984; BURDA, 2007).

Apart from being of great threat to the biodiversity, giant hogweeds are toxic for livestock and people health (Drever and Hunter, 1970a). The stems, leaves, and fruits of the giant hogweed contain noxious sap that raises the skin's sensitivity to the sunlight. Due to the presence of furocoumarins (psoralens) in the cell sap, touching these plants can cause skin irritation, severe dermatitis (phytophotodermatitis) and a second-degree burn. Effects may include welts, rashes, and blistering, followed by pigmented scarring that may persist for as long as six years. The giant hogweeds are also dangerous for children, especially if the juice penetrates into the eyes. In extremely rare instances, full skin thickness burns or epidermal necrosis occur (PATOCKA and Cupalova, 2017).

It is worth mentioning that being a part of the flora of Ukraine the alien species that got adapted to the changing conditions quite rapidly settle new localities, and sometimes intensively increase the number of the species that leads to the phytoinvasions (BURDA et al., 2015). Those alien species include invasive species, in particular the ones being under the research $H$. sosnowskyi and $H$. mantegazzianum (Apiaceae).

Due to the absence of competitors and natural enemies, those giant hogweeds make up dense thickets of the populations Giant sizes, speed of biomass accumulation and a high degree of plasticity allow these plants be able to alter the structure of the population of the aboriginal species, particularly, in the meadow-forest and coastalwater communities, up to their total displacement, in a short period (VYKHOR and PROTS, 2012).

Actually, the spread of the giant hogweeds in Ukraine began from the Transcarpathian region to the Polissya region. Expansion of giant hogweeds in Ukraine took place at the end of 1976, when they began to occupy the disturbed forests and nodes, floodplains, ravines, beams, parks, gardens, roadsides (РRоторороva et al., 2002). The peculiarities of giant hogweeds spread on the territory of Ukraine were enlightened in the publications, in particular on the territory of Polissya (LuKash and Zavyalova, 2003; MykhalyuK et. al., 2017; Кномүак et al., 2019; Oitsius et al., 2020) and Transcarpaphiya (РRотороPova et al., 2006; Simpson et al., 2011; VYKHOR and Prost, 2012). It was pointed out that the harmful for the peoples health wild plants of the mentioned species from the genus of Heracleum (BURDA, 2005) often come out the agricultural landscape of Ukraine. In particular, intensive spread of these two species along the springs and beams in Zhytomir (town Ovruch and village Ruzhyn), Vinnytsya (town Shargorod and village Teplyk) and Kyiv (village Velyka Snyatynka) regions was showed.

The urbanisation favours adventisation of vegetation and exerts a negative effect on Kyiv's biotypes. New locations of invasive species giant hogweeds were recorded within the Holociivskyi forest (BURDA, 2007; BAGATSKA, 2008; ONYSHCHENKO et al., 2016); in the suburbs of the village Khotiv (Kyiv-Svyatoshyn region) and in the local landscape Feofania (GUBAR and KonIAKIN, 2020). A location of single individuals of $H$. sosnowskyi was recorded on the shoreline of the lake Syretske in Kyiv (T. Bahatska personal communication). In this work the comprehensive research of giant hogweeds species was carried out for the first time in Kyiv and its suburbs to find out the ways of the species active spread and their intrusion into various communities.

In our study we aimed to evaluate the possibility of spontaneous spread of giant hogweeds in the secondary range, adaptation of the species to the new conditions of the environment that favour to control of these species' expansion and reduce the threat to the urban ecosystems and citizens' health. We hypothesise that in the secondary range $H$. sosnowskyi and $H$. mantegazzianum settle sites with relatively high temperature, lightening, and soil moisture conditions similar to that in their natural range.

\section{Study species}

The genus Heracleum (Apiaceae) includes 60-148 species of perennial or biennial herbs, distributed in the temperate northern hemisphere and in high mountains as far south as Ethiopia (Tropicos.org. Missouri Botanical Garden, 2021). Centres of the highest species diversity are the Caucasus Mountains (26 species) and China (29 species), particularly 
Hengduan Mountains (Mandenova, 1950; FADING and WATSON, 2005). We presented a brief botanical description of two studied species of the genus Heracleum (H. sosnowskyi, H. mantegazzianum).

Sosnowski's hogweed (H. sosnowskyi) was described as a separate species by I. Mandenova in 1944 (LAPIN̦Š et al., 2002; OBOĻEVIČA, 2001). H. sosnowskyi is biennial or perennial plant of the Caucasus origin (MANDENOva, 1950). Height is usually 1-3 meters. The stem is ridged and sparsely hairy with purple blotches. On the upper surface the leaves are hairless and below slightly hairy. The leaf margins have short rounded teeth. The flowers are white, sometimes pinkish. Outer petals radiate, $9-10 \mathrm{~mm}$ long. Slightly convex compound umbels, $30-50 \mathrm{~cm}$ across 30-75 rays with only short hairs. The fruits are egg shaped or oval; $8-10 \mathrm{~mm}(-15 \mathrm{~mm})$ long, when they are unripe, they are densely hairy. Fruits have very conspicuous oil ducts that do not reach the fruit base (NIELSEN et al., 2005).

Giant hogweed (H. mantegazzianum) is a perennial, monocarpic herb (KRINKE et al., 2005). The native range of $H$. mantegazzianum is the western Caucasus region. Height is usually 3-4 meters and may exceed 5 meters (PAGE et al., 2006). Stems are rigid, stout, typically $5-10 \mathrm{~cm}$ in diameter and are often purple spotted or continuously purple. Leaves are alternate with lower leaves 1-3.0 meters long, compound, irregularly shaped in ternate or pinnate segments, deeply lobed, and irregularly toothed. White or rarely pinkish flowers are clustered in an umbrella-shaped head (umbel) that is up to $80 \mathrm{~cm}$ across with $30-150$ rays (NeILSON et al., 2005; Global Invasive..., 2021). H. mantegazzianum has a thick, yellow branching taproot $15 \mathrm{~cm}$ in diameter and up to $60 \mathrm{~cm}$ long (PAGE et al., 2006; Global Invasive..., 2021). Fruits are dry schizocarps consisting of two mericarp seeds 6-18 $\mathrm{mm}$ long, 4-10 $\mathrm{mm}$ wide and about $1 \mathrm{~mm}$ thick, which are joined until ripening. The endosperm is oily and mature fruits have a strong resinous smell (TILEY et al., 1996).

\section{Materials and methods}

The research was carried out at the territory of Kyiv agglomeration (the total area is 847 square $\mathrm{km}$ ). Its green zone is approximately $49,133.52$ hectares, or $58.80 \%$ from the entire city's territory. The biotic diversity of the city of Kyiv depends mostly on physical and geographical position, and geomorphological structure of the territory, which is a part of the two landscape zones: the zone of the mixed forests or Polissya and forest-steppe zone (MARYNYCH et al., 2003). Kyiv's urban ecosystems comprise various biotopes, where fragments of deciduous forests, coniferous and mixed forests, meadows, hydrotopes, agricultural ecotopes, residential ecotopes, technogenic ecotopes and others prevail (AloshKINA, 2011). By population we mean a number of all the organisms of the same group or species who live in a particular geographical area and are capable of interbreeding. Locality (site) means individual individuals that grow at a distance from the main population and are only separate centers of its expansion.

In the majority of habitats, the isolation between of giant hogweeds populations is absent; consequently, they are inclined to interspecific hybridisation. That's why the morphometrical characteristics (the fruit shape) were used to identify these species. During growing seasons of 2019-2020, the field researches of giant hogweeds populations were carried out by the route method making full florist lists. The lists of plants communities with the participation of these two species were made considering taxonomic summaries (MOSYAKIN and FEDORONCHUK, 1999; Tutin et al., 1964-1994).

The field researches foresaw the establishment of floristic compound of the communities comprised of giant hogweeds by the implementation of the geobotanical description using the methods (WeSTHOFF and MAAREL, 1978) considering population density of invasive species. A total of 34 phytosociological reveles, in accordance with the Braun-Blanquet method, were used to analysis the floristic composition and habitat conditions, in which two Heracleum species occurs in Kyiv agglomeration (BRAUNBLANQUET, 1964). The higher syntaxonomic units are given in accordance with the latest edition of «Vegetation of Europe...» (MucINA et al., 2016).

The size of the trial plot varied from 100 to $8,000 \mathrm{~m}^{2}$ and depended on the number of individuals of the population and the homogeneity of the plant community. It was calculated the number of individuals of giant hogweeds in the pregenerative and generative stages. The computer technologies SAS Plane Portable 14 Final, Coral Draw 15 were used to draw up maps of populations areas and processing the results. Geographic coordinates of spatial location of each population were identified using GPS map 76CSx. On the basis of a detailed classification, three types of the studied populations were identified: invasive type - plants are found in the form of seedlings, juveniles and vegetates individuals and don't complete the full development cycle; normal type - plants are in optimal conditions and have a high percentage of generative individuals; regressive type - plants bloom, bear fruit and do not regenerate generatively (RABOTNOV, 1946; Kravtsiv and CherevKo, 2007).

The assessment of Complex indicator values (CIV) for each population giant hogweeds populations was conducted by processing geobotanical description according to the ecological scales (EllenberG, 1988; Tsiganov, 1983; DIDUKH, 2011). Median values of ten ecological scales were used: thermal climate (Tm), continental climate (Kn), humidity (Om), cryo-climate (Cr), as well as for soils soil humidity (Hd), carbonate content in soil ( $\mathrm{Tr}$ ), nitrogen content $(\mathrm{Nt})$, acidity (Rc), variability of damping (Fh) and light in community (Lc). The numerical of Complex indicator values (for example, lighting Lc1 and Lc2) meant ecological scales of lower and higher values for each species individually (DIDUKH, 2011).

The difference between populations in CIV median was assessed using the Kruskal-Wallis test and follow-up MannWhitney U-test for pairwise comparisons. Both statistical tests were performed in R 4.05 (R CORE TEAM, 2020). We employed the principal component analysis (PCA) to assess the structures of CIV based on data sets for both studied species. To develop the workflow of the analysis, we used the methodology described by Radoslaw Puchalka with co-authors (PuCHALKa et al., 2018). 


\section{Results}

Within the biotopes of Kyiv agglomeration it was found out 17 populations and four localities of giant hogweeds which are the part of the forest, meadow, and riverine fragments (Fig. 1). The total area of populations covered 2,186 hectares.

The number of individuals of giant hogweeds was 4,495, their ontogenetic stage was mainly pregenerative $-3,552$ individuals and generative 943. Table 1 shows ontogenetic and spatial characteristics of studied populations during 2019-2020. We found out that 11 populations are a part of normal type of dynamics (1-3; 6-13, 15-17), one belong to invasion type (14), and two are of regressive type (4-5). The largest number of species within communities with participation of giant hogweeds was presented in populations $10,15,1,7,9$. The number of generative individuals was higher (populations 3, 4, 5) if soil-vegetation cover was altered or at a place of logging under forest canopy. Also, in Table 1, based on geobotanical descriptions according to Brown-Blanquet, the stratification of the population, the projective cover of the species, absolute density of giant hogweeds in $1 \mathrm{~m}^{2}$ and their ontogenetic structure were determined.

Giant hogweeds are a part of various groups of biotopes. Aquatic biotopes are represented by floodplains of the Vita Creek and non-overgrown areas of ponds (C2.1 - population 1, 2; C3.65 - population 12). In herbaceous biotopes (E2.61 - population 13; E2.64 - population 8) the distribution of hogweed was revealed in artificially planted lawns, xeromesophytic and mesoxerophytic artificial grass stands. The largest populations noted in forest biotopes (G11 - population 10, G1.C - populations 3, 14; G1.C3 - population 5, G1.D - population 6) are riverside and gallery forests of Alnus Mill., Populus L., Salix L.; artificial forest plantations, Robinia L. plantings and orchards. In semi-natural biotopes (I2.1 - population 4, I1.2 - population 7, I1.53 - populations 12,17 ), they were found in ecosystems of gardens and garden plots, large parks and fallow fields with groups of perennial weeds. Artificial biotopes (J1.3 - population 11, J4.1 population 9; J6.1 - populations 15,16 ) cover urban and suburban development, underutilized roads, railways and other hard surface areas, as well as areas with construction waste (European Nature Information System, EUNIS).

Population 1. H. sosnowskyi grows in the community of the class Phragmito-Magnocaricetea Klika in Klika et Novak 1941 (MucinA et al., 2016) on a thalweg of the beam, alongside which the stream Vita flows (the suburbs of Kyiv - the village of Khotiv), taking up the area of $1,645 \mathrm{~m}^{2}$. The area is under seasonal flooding, represented by meadowswamp soils with a high aquiferous horizon. A number of giant hogweeds in the population is 333 plant individuals. The total projective coverage is $70 \%$. The basis of the vegetation is made up by: $H$. sosnowskyi, Parthenocissus quinquefolia (L.) Planch., Carex acutiformis Ehrh., Phragmites australis

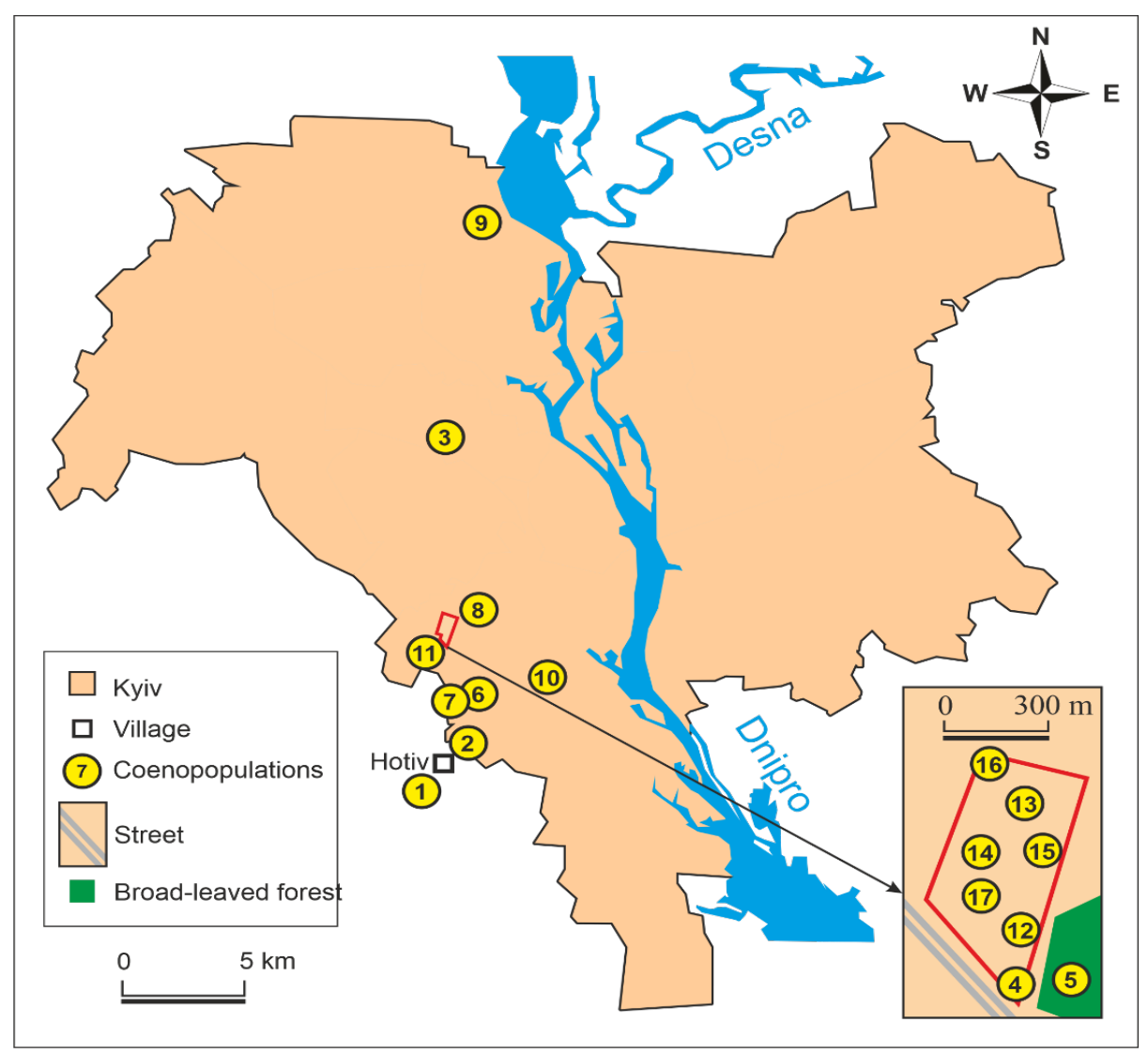

Fig. 1. A schematic map of the giant hogweeds populations areas in Kyiv (made in QGIS with Natural Earth). 


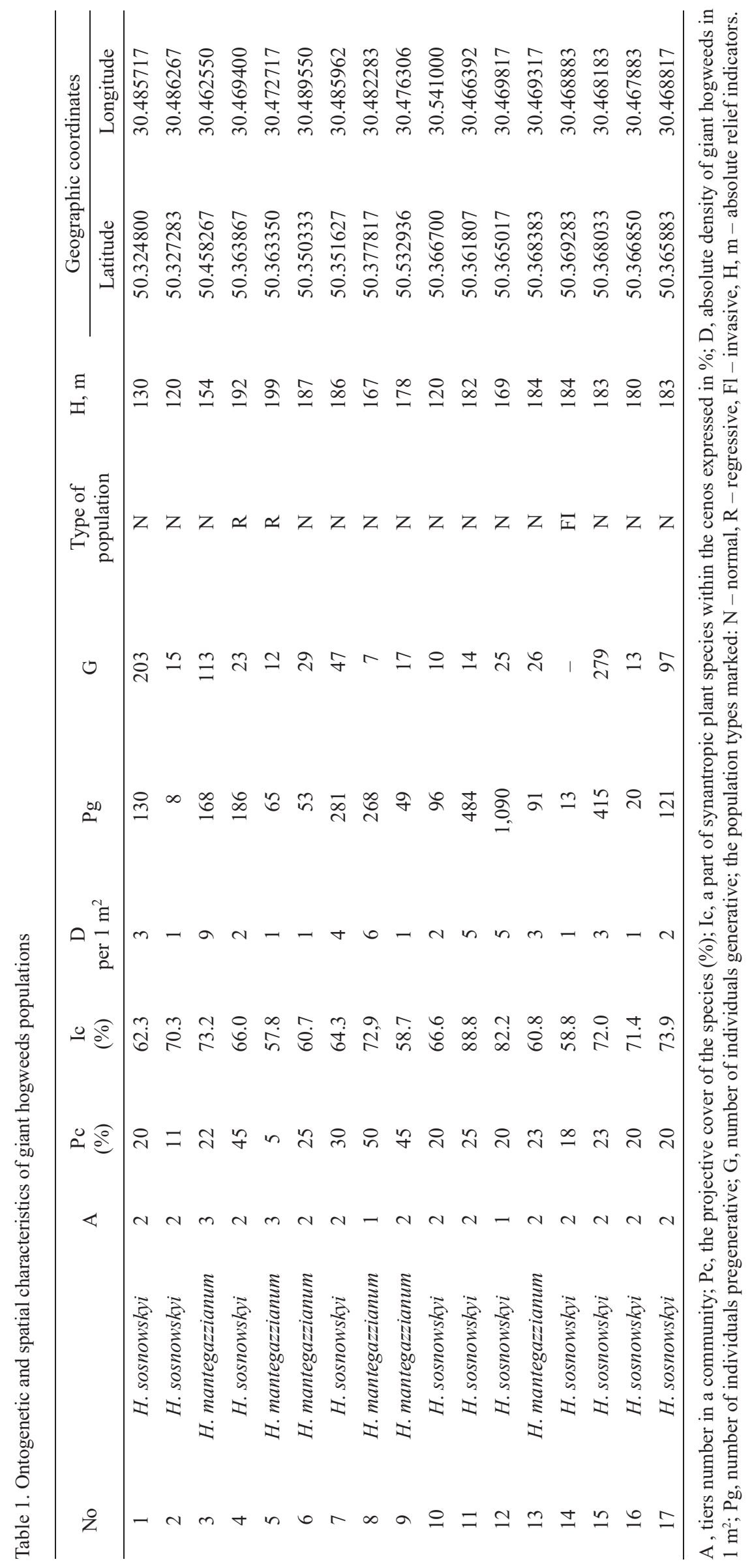


(Cav.) Trin. ex Steud. (diagnostic species); Urtica dioica L., Carex lasiocarpa Ehrh., Geranium palustre L., Equisetum arvense L., Rubus caesius L., Humulus lupulus L., Salix alba L. (constant species) and 79 other plant species. The population includes of 94 plant species from 45 families.

Population 2. H. sosnowskyi in the class community Phragmito-Magnocaricetea (Mucina et al., 2016) alongside the levee near stream Vita together with meadow-swap biotypes (village of Khotiv) occupy the territory of $178 \mathrm{~m}^{2}$. The location is under insignificant seasonal flooding, as the soils are meadow-swap. The number of $H$. sosnowskyi population is 23 individuals. The total projective coverage makes $60 \%$. The basic of the plant coverage is made by: Urtica dioica, Salix alba (diagnosing species); Parthenocissus quinquefolia, Solidago canadensis L., Elymus repens (L.) Gould, Carex acutiformis, Equisetum arvense, Eupatorium cannabium L., Stellaria nemorum L. (constant species), and 40 other plant species. The population includes of 54 plant species from 27 families.

Population 3. H. mantegazzianum grows in the community of the class Robinietea Jurko ex Hadac et Sofron 1980 (Mucina et al., 2016) at the bottom of the beam «Shulyavska», that presents the channel of the already non-existent stream Pischanyi (territory of the Kyiv zoo). The studied population comprises $2,125 \mathrm{~m}^{2}$. The territory is under a slight anthropogenic load: littered with solid household wastes and organic wastes. The soils are sodpodzolic. The number of $H$. mantegazzianum population is 281 individuals. The general projective coverage is $85 \%$. The basis of the plant coverage is composed by: Urtica dioica, H. mantegazzianum, Acer negundo L., Chelidonium majus L., Impatiens parviflora DC (diagnosing species); Parthenocissus quinquefolia, Robinia pseudoacacia L., Acer platanoides L., Ambrosia artemisiifolia L. (constant species) and 36 other plant species. The population includes of 56 plant species from 30 families.

Locality 3 (1). H. mantegazzianum grows down along the beam from the main population 3 at the distance of $50 \mathrm{~m}$. The area is $12 \mathrm{~m}^{2}$, the number of the locality H. mantegazzianum is 6 plant individuals ( 3 ones are pregenerative, and the other 3 are generative individuals). In the undergrowth Acer negundo, Ulmus laevis Pall. are marked. In the grassy level Urtica dioica, Galium aparine L., Solidago canadensis prevail; and Dactylis glomerata L., Elymus repens, Scirpus sylvaticus L. are growing at insignificant numbers.

Population 4. H. sosnowskyi grows in the community of the class Robinietea (MucINA et al., 2016) at the territory of the forest-park zone of the National complex «Expocentre of Ukraine», that adjoins the territory of the National park «Holosiivskyi». The studied population comprises $756 \mathrm{~m}^{2}$. The area is under significant recreational load and littering of solid household wastes was found out. Besides, there is seasonal mowing of grassy vegetation. The soils are sodmoderate and-light-podzolic, sandy and loamy. The number of $H$. sosnowskyi in the population makes 209 individuals. The total projective coverage is $60 \%$. The basis of the vegetation level is made by: Acer negundo, Erigeron annuus (L.) Pers., H. sosnowskyi (diagnosing species); Urtica dioica, Artemisia vulgaris L., Chelidonium majus (constant species) and 41 other plant species. The population includes of 56 plant species from 31 families.

Population 5. H. sosnowskyi grows in the community of the class Robinietea (MucinA et al., 2016) on the area of the forest- park zone of the National complex «Expocenter of Ukraine», that adjoins the territory of National Park «Holosiivskyi». The studied population occupies the area of $351 \mathrm{~m}^{2}$. The locality is under insignificant recreational load, and, also, local weathering is pointed out. The soils are light grey and grey and were formed on the forest and boulder loams. The number of $H$. sosnowskyi in the population is 77 individuals. The total projective coverage is $55 \%$. The basis of the vegetation is made by: Impatiens parviflora, Sambucus nigra L., Urtica dioica, Chelidonium majus, Geranium robertianum L. (diagnosing species); $H$. sosnowskyi, Xanthoxalis stricta (L.) Small, Arrhenatherum elatius (L.) P. Beauv. ex J. Presl \& C. Presl., Geum urbanum L., Quercus robur L., Robinia pseudoacacia (constant species) and 25 other plant species. The population includes of 39 plant species from 26 families.

Population 6. $H$. mantegazzianum grows in the community of the class Robinietea (MuCINA et al., 2016) on the abandoned plantations of nut breeding trees (academic Lebedev street), taking up the area of $200 \mathrm{~m}^{2}$. The area is under significant anthropogenic load: littering by solid household wastes, weeding and destruction of the structure of soilvegetation level in the process of carrying out construction. The soils are light grey on forest loams and sandy in places. The number in the population giant hogweeds is 82 plant individuals. The total projective coverage is $85 \%$. The basis of the vegetation is made by: Urtica dioica, Juglans regia L., Acer negundo, Glechoma hederaceae L., Geum rivale L., Humulus lupulus (diagnosing species); Parthenocissus quinquefolia, H. mantegazzianum, Ballota nigra L., Impatiens parviflora, Quercus rubra L. (constant species) and 15 other plant species. The population includes of 29 plant species from 18 families.

Population 7. H. sosnowskyi grows in the community of the class Artemisietea vulgaris Lohm., Prague. Et al. ex Von Rochow 1951 (Mucina et al., 2016) on the territory of the abandoned fruit-berries plantations within scientificexperimental base of the Institute of Botany of the National Academy of Sciences of Ukraine (Metrologychna street 11B). The studied population takes up the area of $405 \mathrm{~m}^{2}$. The area is under significant anthropological load, particularly, littering by solid household wastes and weeding. The soils are sod and slightly podzolic. The number of giant hogweeds in the population is 328 plant individuals. The total projective coverage is $65 \%$. The basis of the vegetation is made up by: Ambrosia artemisiifolia, Erigeron annuus, Melilotus albus Medik., Acer platanoides L., H. sosnowskyi (diagnosing species); Artemisia vulgaris, Polygonum aviculare L., Convolvulus arvensis L., Cirsium arvense (L.) Scop. (constant species) and 73 other plant species. The population includes of 90 plant species from 29 families.

Locality 7 (1). H. mantegazzianum grows down alongside the beam Feofaniya (the sixth forest block of the park Feofaniya) at the distance of 2 meters from the paved road. The area is $2 \mathrm{~m}^{2}$. The number of the locality $H$. mantegazzianum is 6 pregenerative plant individuals. The 
wooden tier is made up by Quercus robur, Carpinus betulus L. The closeness of the trees crowns reaches $0.4-0.5$. In the vegetation Chelidonium majus, Conium maculatum L., Dactylis glomerata, Lysimachia nummularia L., Urtica dioica and others prevails.

Locality 7 (2). H. sosnowskyi grows on the flowerbed alongside the building (Academic Zabolotnyi street, 148) at the distance of 580 meters from population 7 . The area is $20 \mathrm{~m}^{2}$. The number of the locality $H$. sosnowskyi makes up 8 pregenerative and 7 generative plant individuals. Single individuals of self-seeding Robinia pseudoacacia, Ulmus glabra Huds. were found out. The wooden tier is made up by Quercus robur, Carpinus betulus. In the grassy tier Solidago canadensis, Conyza canadensis (L.) Cronq., Chenopodium album L., Portulaca oleracea L., Setaria viridis (L.) P. Beauv., Bidens frondosa L. and others were noted.

Population 8. H. mantegazzianum grows in the community of the class Epilobietea angustifolii Tx. et Preising ex von Rochow 1951 (Mucina et al., 2016) on the territory of National complex «Expocenter of Ukraine» under garden-park plantation (Academic Hlushko Avenue, 1). The studied population occupies the area of $96 \mathrm{~m}^{2}$. The territory is under the significant recreational load: weeding, trampling of the grass cover, periodical mowing. The soils are urbansoils. The H. mantegazzianum in the population reaches 275 plant individuals. The total projective coverage is $45 \%$. The basis of vegetation is made up by: Elymus repens, Carex praecox Schreb., Trifolium medium L., Urtica dioica (diagnosing species); Polygonum aviculare, Taraxacum officinale Wigg (constant species) and 29 other plant species. The population includes of 37 plant species from 23 families.

Population 9. $H$. mantegazzianum grows in the community of the class Epilobietea angustifolii Tx. et Preising ex von Rochow 1951 (Mucina et al., 2016) near lake Redkyne (Obolon district in Kyiv), taking up area of $128 \mathrm{~m}^{2}$. The area is under significant recreational load: weeding, trampling of the grass cover. The soils are sodsandy and podzolic. The number of $H$. mantegazzianum in the population makes up 66 plant individuals. The total projective coverage is $80 \%$. The basis of the vegetation is made up by: Calamagrostis canescens (Weber) Roth, Asclepias syriaca L., Artemisia vulgaris, Rubus caesius, Dactylis glomerata, H. mantegazzianum, Bromus inermis Leyss., Erigeron annuus (diagnosing species); Aristolochia clematitis L., Salix caprea L., Solidago canadensis (constant species) and 48 other plant species. The population includes of 63 plant species from 26 families.

Locality 9 (1). H. mantegazzianum grows behind the railways from the main population 9 at the distance of $45 \mathrm{~m}$. The area is $4.0 \mathrm{~m}^{2}$. The number of the locality H. mantegazzianum is 13 plant individuals (10 are pregenerative, 3 are generative ones). In the grassy tier Calamagrostis canescens, Artemisia vulgaris, Erigeron annuus and others.

Population 10. H. sosnowskyi grows in the community of the class Salicetea purpureae Moor 1958 (MucinA et al., 2016) on the territory of the National natural park «Holosiivskyi» (Kyiv ponds). The studied population approximately covers $1,340 \mathrm{~m}^{2}$. The locality is situated under insignificant recreational load: weeding, trampling of the grass cover. The soils are light-grey, meadow-swamp. The number of giant hogweeds in the population is 106 plant individuals. The total projective coverage is $60 \%$. The basis of the vegetation is made by: Elymus repens, Urtica dioica, Iva xanthiifolia Nutt. (diagnosing species); Parthenocissus quinquefolia, Solidago canadensis, Conyza canadensis, Lactuca serriola L., Ambrosia artemisiifolia, Polygonum aviculare (constant species) and 93 other plant species. The population includes of 105 plant species from 45 families.

Population 11. H. sosnowskyi grows in the community of the class Robinietea (Mucina et al., 2016) in the Academic Zabolotnyi, 64 street (the outskirts of Feofaniya market), covering the area of $243 \mathrm{~m}^{2}$. The area is under anthropogenic load: weeding, trampling, and mowing. The soils are urbansoil. The number of giant hogweeds in the population is 498 plant individuals. The total projective coverage is $75 \%$. The basis of the vegetation is made by: Glechoma chederaceae, Ballota nigra, Urtica dioica, Elymus repens, Conyza canadensis (diagnosing species); Reynoutria $\times$ bohemica Chrtek \& Chrtkova, Dactylis glomerata, Linaria vulgaris Mill., Sonchums oleraceus L., Erigeron annuus, Xanthoxalis stricta (constant species) and 37 other plant species. The population includes of 54 plant species from 24 families.

Population 12. H. sosnowskyi grows in the community Artemisia vulgaris (MucINA et al., 2016) on the territory of forest-steppe zone of National complex «Expocenter of Ukraine», Academic Hlushkov Avenue, 1. The studied population covers $1,345 \mathrm{~m}^{2}$. The territory is under significant anthropogenic load: weeding, trampling of the grass cover, mowing. The soils are grey forest, urbansoils. The number of giant hogweeds in the population counts 1,115 plant individuals. The total projective coverage is $60 \%$. The basis of the vegetation is made by: Solidago canadensis, Elymus repens, Achillea millefolium L., Ballota nigra (diagnosing species); Artemisia vulgaris, Lysimachia nummularia, Plantago major L., Potentilla argentea L., Trifolium repens L., (constant species) and 24 other plant species. The population includes of 39 plant species from 20 families.

Population 13. $H$. mantegazzianum grows in the community of the class Molinio-Arrhenatheretea R. Tx. 1937 (Mucina et al., 2016) near the (National complex «Expocenter of Ukraine», Academic Hlushkov Avenue, 1), covering the area of $96 \mathrm{~m}^{2}$. The locality is situated under the anthropogenic load. The number of $H$. mantegazzianum in the population is 117 plant individuals. The total projective coverage is $60 \%$. The basis of the vegetation is made up by: Arrhenatherum elatius, Solidago canadensis, Vicia cracca L., Dactylis glomerata (diagnosing species); Ballota nigra, Urtica dioica (constant species) and 18 other plant species. The population includes of 24 plant species from 15 families.

Population 14. H. sosnowskyi grows in the community of the class Robinietea (MucinA et al., 2016) on the territory of culture phytocenosis of the forest-park part of the National complex «Expocenter of Ukraine» (Academic Hlushkov Avenue, 1). The studied population covers $500 \mathrm{~m}^{2}$. The territory is under significant anthropogenic load: weeding, 
trampling of the grass cover. The soils are grey forest. The number of giant hogweeds in the population is 13 plant individuals. The total projective coverage is $45 \%$. The basis of the vegetation is made up by: Acer negundo, Euonymus europaeus L., Chelidonium majus, Humulus lupulus, Urtica dioica (diagnosing species); Carpinus betulus, Populus alba L., Rubus caesius, Sambucus nigra (constant species) and 24 other plant species. The population includes of 35 plant species from 23 families.

Population 15. H. sosnowskyi grows in the community of the class Molinio-Arrhenatheretea (MucinA et al., 2016) on the territory of the lost landscape and architectural expositions (National complex «Expocenter of Ukraine», Academic Hlushkov Avenue, 1). The studied population covers the area of $8,245 \mathrm{~m}^{2}$. The locality is situated under the significant anthropogenic load: weeding, trampling, littering by solid household wastes, organic wastes. The soils are grey forest, urbansoils. The number of giant hogweeds in the population makes up 694 plant individuals. The total projective coverage is $65 \%$. The basis of the vegetation is made up by: Arrhenatherum elatius, Calamagrostis canescens, Dactylis glomerata, Solidago canadensis, Taraxacum officinale (diagnosing species); Carex hirta L., Chenopodium album L., Elymus repens, Polygonum aviculare, Urtica dioica (constant species) and 80 other plant species. The population includes of 94 plant species from 39 families.

Population 16. H. sosnowskyi grows in the community of the class Molinio-Arrhenatheretea (MucINA et al., 2016) on the territory of National complex «Expocenter of Ukraine» (Academic Hlushkov Avenue, 1), covering the area of $772 \mathrm{~m}^{2}$. The territory is situated under the significant anthropogenic load: weeding, trampling, littering by solid household wastes, organic wastes. The soils are urbansoils. The number of giant hogweeds in the population is 33 plant individuals. The total projective coverage is $60 \%$. The basis of the vegetation is made up by: Dactylis glomerata, Elymus repens, Solidago canadensis (diagnosing species); Erigeron canadensis, Ballota nigra, Heracleum sosnowskyi (constant species) and 20 other plant species. The population includes of 28 plant species from 16 families.

Population 17. H. sosnowskyi grows in the community of the class Artemisietea vulgaris (MuCINA et al., 2016) near agrophytocenosis of the National complex «Expocenter of Ukraine», Academic Hlushkov Avenue, 1. The studied population covers the area of $1,723 \mathrm{~m}^{2}$. The locality is situated under the significant anthropogenic load: weeding, trampling. The soils are medium-humus. The number of giant hogweeds in the population is 218 plant individuals. The total projective coverage is $60 \%$. The basis of the vegetation is made up by: Solidago canadensis, Tragopogon dubius Scop., Calamagrostis canescens (diagnosing species); Ballota nigra (constant species) and 17 other plant species. The population includes of 23 plant species from 9 families.

The indicators of moisture supply of the soils (Hd) in the majority of the populations ranged from 6.7 to 16.9 corresponding to the dry forest-meadow type (Fig. 2). The soil's moisture (Fh) indicator ranged between 4.5 and 9.1 corresponding the relatively stable moisture from weak to moderate levels (Fig. 2).

The indicator values of general salt regime of the communities varied between 3.2 and 10.0 and corresponded to poor and salt-enriched soils contained $\mathrm{HOC}_{3}$. The value of nitrogen content indicator ranged between 4.5 and 10.0 pointing to both poor and reach in nitrogen soils. The Rcfactor values of 2.1-11.0 indicated acidic and slightly acidic soils. The light (Lc), a limiting ecological factor of spreading of the studied species (DiDUKH et. al., 2000; Кномуак et al., 2019), varied between 1.0-5.7 and corresponded to sciophytic conditions of light and shadow forests (Fig. 2). The analysis of the vegetation communities by climatic factors indicated that the studied plants communities formed in the conditions from the sub-oceanic to subcontinental $(\mathrm{Kn}=3.2-14.0)$ climate. The study area referred from nemoral and boreal forest to sub-mediterranean thermal zone $(\mathrm{Tm}=5.0-13.0)$ within the range of frost resistance $(\mathrm{Cr}=$ 4.3-12.3), which is typical for the regions with severe and warm winters. The studied plants' communities formed in the conditions from sub-arid to sub-humid climate $(\mathrm{Om}=$ 3.9-11.0) (Fig.2).

According to the test Kruskal-Wallis with adjustment to connection (Table 2), statically significant difference in median values CIV for the population studied by indicators Lc2 $(17=27.166, p=0.03967)$ and Tm1 $(17=31.964, p=$ $0.01011)$ was established. The variation Lc2 is connected to the populations $4-5$ and 14 , which are characterised by much lower medial values.

For $\mathrm{Tm} 1$ the indicators are connected to the populations 3 and 14. According to the results of the floristic analysis by species composition no significant difference between the populations was detected to confirm their belonging to one of the vegetation class - Robinietea.

Table 2. The Kruskal-Wallis tests for medians of CIV for vegetation plots between 17 study populations. The statistically significant p-values are marked in bold

\begin{tabular}{cccc}
\hline CIV & Chi-squared & df & p-value \\
\hline Tm1 & 31.964 & 16 & $\mathbf{0 . 0 1 0 1 1}$ \\
Tm2 & 19.14 & 16 & 0.2615 \\
Kn1 & 17.763 & 16 & 0.338 \\
Kn2 & 12.546 & 16 & 0.7056 \\
Om1 & 19.962 & 16 & 0.2219 \\
Om2 & 13.977 & 16 & 0.6004 \\
Cr1 & 24.629 & 16 & 0.07663 \\
Cr2 & 18.999 & 16 & 0.2687 \\
Hd1 & 25.045 & 16 & 0.06904 \\
Hd2 & 25.613 & 16 & 0.05973 \\
Tr1 & 15.629 & 16 & 0.4792 \\
Tr2 & 20.213 & 16 & 0.2108 \\
Nt1 & 11.443 & 16 & 0.7813 \\
Nt2 & 8.1834 & 16 & 0.9432 \\
Rc1 & 15.781 & 16 & 0.4683 \\
Rc2 & 10.348 & 16 & 0.8482 \\
Lc1 & 8.9266 & 16 & 0.9164 \\
Lc2 & 27.166 & 16 & $\mathbf{0 . 0 3 9 6 7}$ \\
Fh1 & 12.94 & 16 & 0.6771 \\
Fh2 & 12.441 & 16 & 0.7131 \\
\hline
\end{tabular}



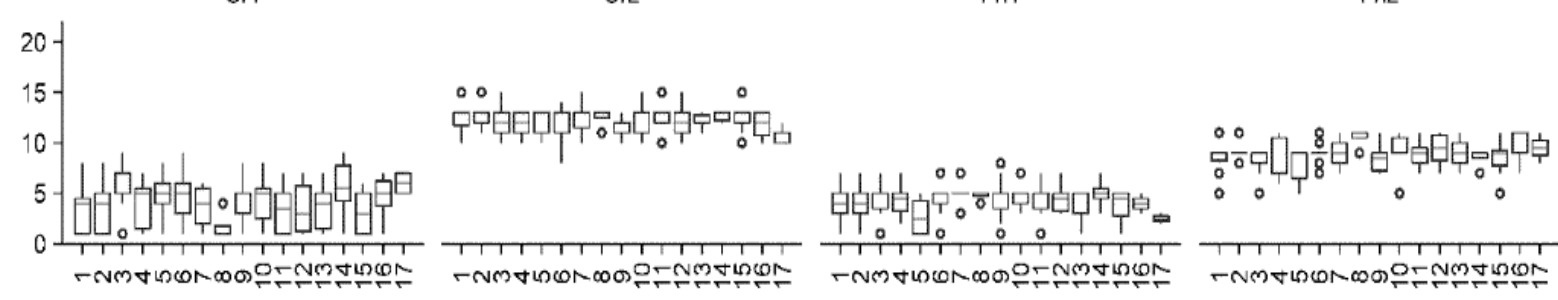

Hd1

$\mathrm{Hd} 2$

$\mathrm{Kn} 1$

$\mathrm{Kn} 2$
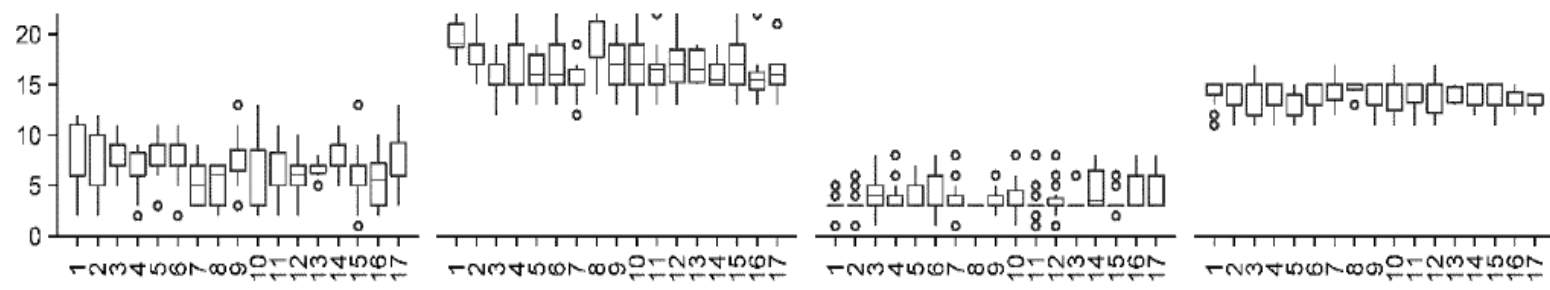

Nt1

-NM母LON

Lc1

Lc2

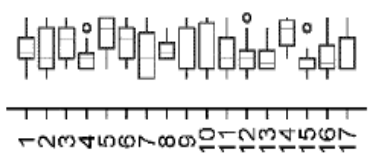

$\mathrm{Om} 2$
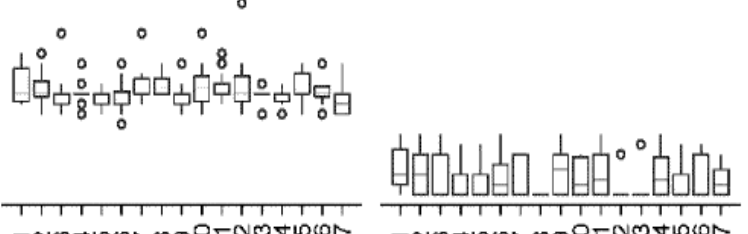

-NMVLON

$\operatorname{Tr} 1$

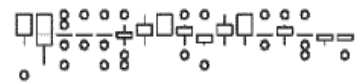

-NM

$\operatorname{Tm} 2$

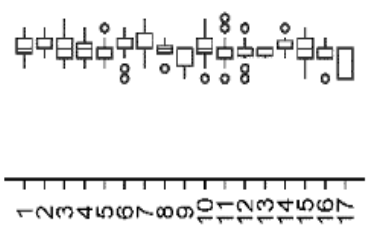

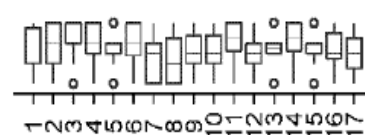

Rc1

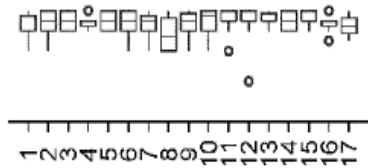

Rc2
- Nल
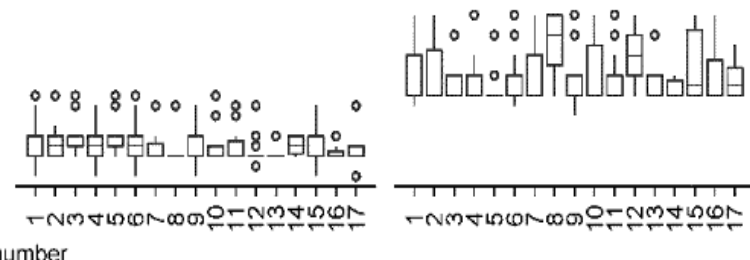

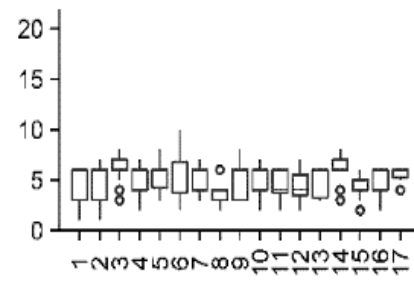

Site number

Fig. 2. Analysis of CIV for study populations: the lower and upper hinges indicate the 25 th and 75 th percentiles, the horizontal lines denote the median values, the whiskers extend from the hinges to the largest and smallest values within the 1.5 inter-quartile range, and the points indicate outliers. CIV codes: Tm - climate thermal mode, $\mathrm{Kn}$ - continental, Om - arid/ humid, $\mathrm{Cr}$ - cryophytes, $\mathrm{Hd}$ - mesophytes, $\mathrm{Tr}$ - eutrophes, $\mathrm{Nt}$ - nitrophiles, $\mathrm{Rc}$ - acidophilic, Lc - helioscyophytes, $\mathrm{Fh}-$ contrastophobes.

Figure 3 presents the results of principal component analysis (PCA) that performed using the CIV data set for Tm1 and Lc2. The first two principal components were required to extract 67.1 the total inertia for $H$. sosnowskyi and $81.1 \mathrm{H}$. mantegazzianum. The first principal component PC1 explained ca. $53.4 \%$ and $61.3 \%$ of the total Tm1 and Lc2 variance and the second component PC2 explained ca. $13.7 \%$ and $19.8 \%$ of the total inertia in species $H$. sosnowskyi and $H$. mantegazzianum respectively. The PC1-2 at factor maps clearly split CIV up into two groups, i.e with higher Lc2 and lower Tm1 along negative PC1 and with lower Lc2 and higher Tm1 along positive PC1. The populations of both species tend to set the sites with higher Lc2 and lower Tm1, i.e. clear open-space and less hot territories (Figure 3: A, C) (KHOMYAK et al., 2019; LEPESHKINA, 2019). 

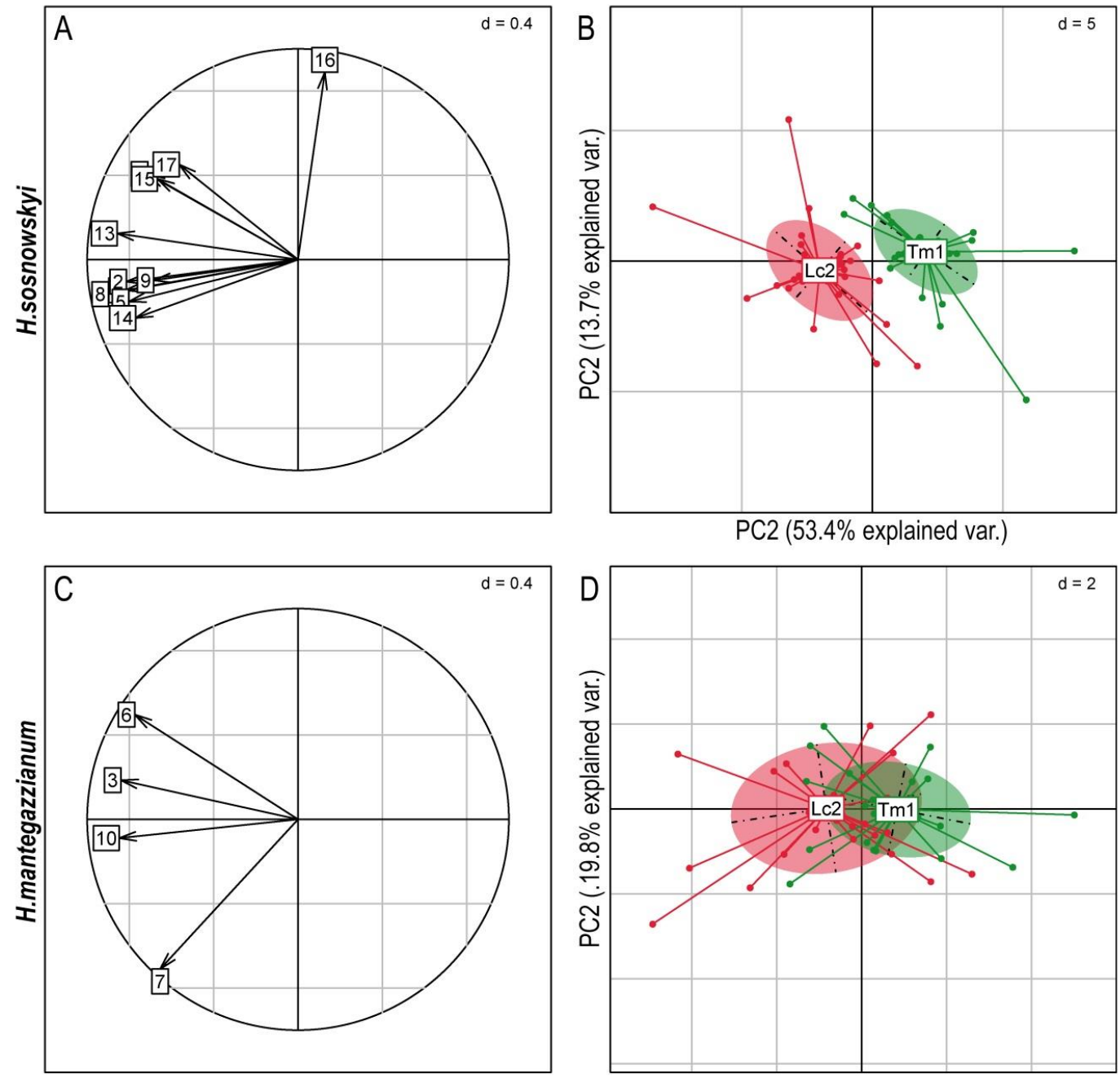

PC2 (61.3\% explained var.)

Fig. 3. The results of PCA analysis applied separately to two Heracleum species: correlation matrix, i.e. scores, for the populations (A, C) and factor maps, i.e. scores, for Tm1 and Lc2 values (B, D).

\section{Discussion}

The systematic analysis of the plant species of the populations' giant hogweeds showed that most plants belonged to: Asteraceae (38), Poaceae (31), Rosaceae (16), Lamiaceae (11) plant families. The participation of other families is significantly reduced. According to the ecology and cenotic confinement in the structure of the community with participation of giant hogweeds the synanthropic species $(40.7 \%)$, forest species $(24.0 \%)$, meadow species $(22.9 \%)$ prevail. The part of synanthropic species in populations varies from 57.8 to $88.8 \%$ (Table 1 ). The basis of populations is made up by synanthropic plants which belong to forest and meadow biotopes with domination of rhizomatous perennial herbs. In some populations the activity of alien invasive species is observed: Solidago canadensis (present in 16 populations), Erigeron annuus (15), Acer negundo, Ballota nigra (13), Parthenocissus quinquefolia (12), Conyza canadensis (11), Impatiens parviflora (9), Robinia pseudoacacia, Ambrosia artemisiifolia (8). The percentage of native plant species in average makes $38.1 \%$.
The studied species in the primary area grow in the middle and upper belts of the mountainous forests, on the meadows and forest-meadows of the beech and fir-beech woods and in the beech crooked forests. The species are also met at the alpine meadows of the subalpine belt and at the river banks at the foothill forest-steppe zone of the Northern Caucasus (Mandenova, 1950; PyseK, 1991; LUNEVA, 2014).

In the secondary area the plants prefer anthropogenically altered plants communities with well-lit areas with fertile soils. However, they also may conquer less fertile soils (JAHODOva et al., 2007). The studied species are widely spread at wastelands and roadsides, woodlands and on the borders of forests and fields, on ravines and beams, springs and rivers valleys. A number of European researchers provide examples of different plants communities where the studied species penetrate (SoBISz, 2007; ABramova et al., 2017; KHOMYAK et al., 2019; AREPIEVA et al., 2021).

Mainly these are the classes of ruderal communities Artemisietea, Epilobietea (SobISz, 2007; Abramova et al., 2017; КHOMYAK et al., 2019; ArEPIEVA et al., 2021), 
Bidentetea Tx. et al. ex von Rochow 1951 (DIDUKH et al., 2016), forest communities - Salicetea purpurea and QuercoFagetea (Кномуак et al., 2019; DiDukH et al., 2016) and meadowland community - Molinio-Arrhenatheretea (KномуAK et al., 2019; DiDUKH et al., 2016) vegetation. According to the results of our research, for the area of Kyiv urban agglomeration the growth of $H$. sosnovskyi and $H$. mantegazzianum is indicated in the plants communities of six classes. The majority of the populations is located in the classes of ruderal plant communities Robinietea (populations 3-6, 11, 14), Artemisietea (populations 7, 12, 17) and Epilobietea (populations 8-9). The classes MolinioArrhenatheretea, Phragmi-Magnocaricetea and Salicetea purpureae are represented only in 5 populations. In our opinion, this is due to the anthropogenic transformation of the study area, where the presence of such plants communities is limited.

According to the ecological specification, which was identified by the ecological scales (ELLENBERG, 1974, 1988; TsigANOV, 1983; DiDUKH, 2011), it should be mentioned that the studied species prefer lit and warm growth conditions (Fig. 2, Table 2). These are the ruderal communities with the participation of Robinia pseudoacacia which form the sparse thickets that are more favorable conditions for the studied species. These conditions are explained by higher temperatures of urban environment (KLAUSNITZER, 1987). The other essential differences according to the ecological indicators were not indicated. According to the results of the research $H$. sosnowskyi and $H$. mantegazzianum grow in these conditions and are ecologically adapted species.

The results indicate broader ecological plasticity of $H$. mantegazzianum in relation to the ecological values Lc2 and Tm1. H. sosnowskyi is less plastic in terms of Lc2 and Tm1. Thus, this analysis indicates a higher ecological potential of $H$. mantegazzianum than $H$. sosnowskyi. But these insignificant differences will not negatively affect the condition, generative recovery and distribution of giant hogweeds in the study and adjacent territories.

\section{Recommendations for the control and elimination of the localities of giant hogweeds}

On the territory of the Kyiv urban agglomeration the populations of giant hogweeds occupy about 2.2 hectares. Caution should be taken when handling these weeds. Removing it manually becomes very difficult because of the danger caused by its sap. In order to avoid the spread of populations with their participation, methods of population control have been proposed and adapted according to international standards (NIELSEN et al., 2005):

- For populations with the number of individuals from 1 to 50: pulling out by hand, cutting out roots, removing umbrellas, mowing (any habitat); chemical processing (agricultural land, pastures).

- For populations with the number of individuals from 50 to 1,000: mowing, intensive grazing (any habitat); chemical processing, soil plowing (agricultural land, pastures). All recommended methods should be carried out several times, taking into account the growing season - during germination and before fruiting.
The role of the main components (Tm1 and Lc2) in the general variability of ecological conditions for the populations of giant hogweed in kyiv indicates the active distribution of species in open-space territories. Therefore, to prevent further infestation, the clogging of such areas should be monitored. It is also necessary to maintain natural communities of open-space territories, preventing the expansion of ruderal plant communities.

\section{Conclusion}

According to the results of our research, for the area of Kyiv urban agglomeration the growth of giant hogweeds is indicated in the plants communities of six classes. From our point of view, giant hogweeds in the populations of Kyiv agglomeration are able to lessen the areas of numerous populations of native species, especially in meadow and forest communities, and rapidly accumulate biomass. According to the results of CIV, a difference was established in the ecological indicators Lc2 and Tm1 for the studied populations. Analysis of PCA diffraction relative to Lc2 and Tm1 shows a broad ecological plasticity of $H$. mantegazzianum and a narrower one for $H$. sosnowskyi. This indicates that these adventive species fully adapted to the new environment in secondary range. $H$. sosnowskyi and $H$. mantegazzianum behave as aggressive species which are able to invade into new ruderal communities: Robinietea, Artemisietea, Epilobietea. It was found out that increase in numbers of the seedlings, juveniles and immature individuals were observed on the regularly mowed areas. The data about invasion of the giant hogweeds can be used to monitoring the invasive species in Kyiv biotopes, especially in populations $4-5,8,12-17$ which belong to the recreational area of the Natural Reserve near Expocenter of Ukraine. The studied species belong to invasive plant species in Ukraine and are characterized by extremely high effect on the environment and high invasive potential. They are rather difficult to control and effective measures are quite expensive.

\section{Acknowledgements}

The work contains the results of the scientific project «The ways and mechanisms of biota transformation in the conditions of the environment global changes» (grant 0120U103385), which is supported by the National Academy of Sciences of Ukraine. The authors are sincerely thankful to Raisa Burda for significant remarks and consultations and Maksym Netsvetov for assistance in statistical data analysis and text editing.

\section{References}

Abramova, L.M., Chernyagina, O.A., Devyatova, E.A., 2017. Invasive species in Kamchatka: distribution and communities. Botanica Pacifica. A Journal of Plant Science and Conservation, 6 (1): 3-12. https://doi.org/: $10.17581 /$ bp. 2017.06101 
Aloshkina, U.M., 2011. Poshyrennia ta kharakterystyka ridkisnykh biotopiv $\mathrm{m}$. Kyieva [Distribution and characteristics of the rare habitats in Kyiv city]. Ukrainskyi Botanichnyi Zhurnal, 68 (1): 76-90.

Andersen, U.V., Calov, B., 1996. Long-term effects of sheep grazing on giant hogweed (Heracleum mantegazzianum). Hydrobiologia. 340 (1-3): 277-284.

Arepieva, L.A., Arepiev, E.I., KaZakov, S.G., 2021. Rasprostranenie borshchevika Cosnovskogo (Heracleum sosnowskyi Manden.) na yuzhnoj granice vtorichnogo areala $\mathrm{v}$ evropejskoj chasti Rossii [Distribution of Sosnovsky hogweed (Heracleum sosnowskyi) on the southern border of the secondary range in the European part of Russia]. Rossijskij Zhurnal Biologicheskih Invazij, 2: $2-15$.

BAGATSKA, T.S., 2008. Novi mistseznakhodzhennia zanosnykh roslyn Artemisia argyi Leveillie et Vaniot i Heracleum sosnowskyi Manden. na berehakh kyivskykh vodoim [Finds of new localities of alien plants Artemisia argyi Leveilie et Vaniot and Heracleum sosnowskyi Manden. near Kyiv water boides]. Ukrainskyi Botanichnyi Zhurnal, 65 (4): 535-543.

BaležentienĖ, L., Stankevičienė, A., SniešKienĖ, V., 2013. Heracleum sosnowskyi (Apiaceae) seed productivity and establishment indifferent habitats of central Lithuania. Ekologija, 59 (3): 123-133. https://doi.org/ 10.6001/ ekologija.v59i3.2795.

Biological invasions: a growing threat to biodiversity, human health and food security, 2012. Policy recommendations for the Rio+20 process drafted by IUCN SSC Invasive Species Specialist Group and Invasive Species Initiative. IUCN Policy Brief. [cit. 2021-03-11]. http://www.issg. org/pdf/RioPolicybrief.pdf.

Braun-Blanquet, J., 1964. Pflanzensoziologie. Grundzüge der Vegetationskunde [Plant sociology. Fundamentals of vegetation science]. 3rd edition. Wien-New York: Springer Verlag. 865 p.

Burda, R.I., 2005. Porivnialnyi analiz lokalnykh fitobiot $\mathrm{v}$ otsintsi ahrobioriznomanitnosti [Comparative analysis of local phytobiota in the assessment of agrobiodiversity]. In Ahrobioriznomanittia Ukrainy: teoriia, metodolohiia, indykatory, pryklady. Knyha 2. Kyiv: Nichlava, p. 165 193.

Burda, R.I., 2007. Nebezpeka roslynnykh invazii u Holosiivskomu lisi [The danger of plant invasions in the Holosiivskyi forest]. In Ekolohiia Holosiivskoho lisu: Monohrafia. Kyiv: Fenix, p. 42-60.

Burda, R.I., Pashkevich, N.A., Boyko, G.V., Fitsailo, T.V., 2015. Chuzhoridni vydy okhoronnykh flor Lisostepu Ukrainy [Alien species of protected flora of the foreststeppe of Ukraine]. Kyiv: Naukova Dumka. 119 p.

CAfFreY, J.M., 1999. Phenology and long-term control of Heracleum mantegazzianum. Hydrobiologia, 415: 223 228. https://doi.org/10.1023/A:1003854221931

Case, M.A., Beaman, J.H., 1992. Heracleum mantegazzianum (giant cow parsnip): another exotic in the Michigan flora. Michigan Botanist, 31: 152-154.

Centre for Agriculture and Biosciences International (CABI), 2019. [cit. 2021-02-26]. https://www.cabi.org/isc/ datasheet/108958
Csiszár, Á., Kézdy, P., Korda, M., Bartha, D., 2020. Occurrence and management of invasive alien species in Hungarian protected areas compared to Europe. Folia Oecologica, 47 (2): 178-191. https://doi.org/10.2478/ foecol-2020-0021

DiDukh, Ya.P., 2011. The ecological scales for the species of Ukrainian flora and their use in synphytoindication. Kyiv: Phytosociocentre. $176 \mathrm{p}$.

Didukh, Ya., Plyuta, P., Protopopova, V., Ermolenko, V., Korotchenko, I., Karkutsiev, G., Burda, R., 2000. Ecoflora of Ukraine. 1. Kyiv: Fitosotsiosentr. 284 p.

Drever, J. C., Hunter, J.A., 1970a. Giant hogweed dermatitis. Scottish Medical Journal, 15 (9): 315-319.

EllenberG, H., 1988. Vegetation ecology of Central Europe. Cambridge: Cambridge University Press. 731 p.

EUROPEAN COMMISSION, 2017. Invasive alien species of Union concern. Luxembourg: Publications Office of the European Union. https://ec.europa.eu/environment/ nature/pdf/IAS_brochure_species.pdf

European Nature Information System (EUNIS). [cit. 2021-0302]. https://eunis.eea.europa.eu/habitats.jsp

European Strategy on Invasive Alien Species, 2015. Convention on the Conservation of European Wildlife and Habitats (Bern Convention). $67 \mathrm{p}$.

FAding, P., Watson, M.F., 2005. Heracleum. In Flora of China. Vol. 14 (Apiaceae through Ericaceae). Ed. by Flora of China Editorial Committee. Beijing: Science Press; St Louis: Missouri Botanical Garden Press, p. 194.

FeHÉr, A., 2000. The current distribution Heracleum mantegazzianum in district Nitra. Rosalia, 6: 79-82.

Global Invasive Species Database (GISD), 2021. Species profile Heracleum mantegazzianum. [cit. 2021-03-11]. http://www.iucngisd.org/gisd/species.php?sc $=418$

Gubar, L.M., Koniakin, S.M., 2020. Invaziini chuzhoridni vydy roslyn urochyshcha «Feofaniia» [Invasive alien species of plants of the local landscape Feofania]. Naukovo-praktychnyi Zhurnal «Ekolohichni Nauky». 31: 167-173.

Jahodová, S., Fröberg, L., Pysek, P., Geltman, D., Trybush, S., KARP, A., 2007. Taxonomy, identification, genetic relationships and distribution of large Heracleum species in Europe. In Pysek, P., Cock, M.J.W., Nentwig, W., Ravn, H.P. (eds). Ecology and management of giant hogweed (Heracleum mantegazzianum). Wallingford, UK: CAB International, p. 1-19.

Kabuce, N., Priede, N., 2010. NOBANIS - Invasive Alien Species Fact Sheet - Heracleum sosnowskyi. Online Database of the European Network on Invasive Alien Species - NOBANIS. [cit. 2021-03-09]. http://www. nobanis.org

Khomyak, I., Demchuk, N., Kotsyuba, I., Yastrebova, Ya., 2019. Ekoloho-tsenotychna kharakterystyka populiatsii Heracleum sosnowskyi Manden na terytorii Tsentralnoho Polissia [Ecological-cenotic population characteristic Heracleum sosnowsky in the territory of Central Polissya]. Ekolohichni Nauky: Naukovo-praktychnyi Zhurnal, 24 (1): 126-129. https://doi.org/10.32846/2306-9716-2019$1-24-2-25$

Klausnitzer B., 1987. Ökologie der Grossstadtfauna. Leipzig. 246 p. 
KLima, K., Synowiec, A., 2016. Field emergence and the longterm efficacy of control of Heracleum sosnowskyi plants of different ages in southern Poland. Weed Research, 56: 377-385. https://doi.org/10.1111/wre.12214

Kuingenstein, F., 2007. NOBANIS - Invasive Alien Species Fact Sheet - Heracleum mantegazzianum. Online Database of the North European and Baltic Network on Invasive Alien Species - NOBANIS. [cit. 12-03-2021]. www.nobanis.org

Kravtsiv, R.Y., Cherevko, M.V., 2007. Osnovy populyatsiynoyi ekolohiyi [Fundamentals of population ecology]. Study guide. Lviv: Terus. 228 p.

Krinke, L., Moravcova, L., Pysek, P., Jarosik, V., Pergl, J., Perglova, I., 2005. Seed bank of an invasive alien, Heracleum mantegazzianum, and its seasonal dynamics. Seed Science Research, 15 (3): 239-248. https://doi. org/10.1079/SSR2005214

Laman, N.A., Prokhorov, V.N., Maslovskiy, O.M., 2009. Gigantskie borshcheviki - opasnye invazivnye vidy dlya prirodnykh kompleksov $i$ naseleniya Belarusi [Giant hogweeds - dangerous invasive species for natural complexes and the population of the Belarus]. Minsk: Institut eksperimentalnoy botaniki im. V.F. Kuprevicha NAN Belarusi. $40 \mathrm{p}$.

Lamdon, P.W., PyšEK, P., Basnou, C., Hejda, M., Arianoutsou, M., Essl, F., Jarošík, V., Pergl, J., Winter, M., Anastasiu, P., Andriopoulo, P., Bazo, I., Brundu, G., Celesti-Grapow, L., Сhassot, P., Delipetro, P., Josefsson, M., Kark, S., Klotz, S., Kokkoris, Y., Kühn, I., Marchante, H., Perglova, I., Pino, J., Vilì, M., ZiKo, A., Roy, D., Hulme, P.E., 2008. Alien flora of Europe: species diversity, temporal trends, geographical patterns and research needs. Preslia, 80: $101-149$.

Lapin̦š, D., BĒrzin̦š, A., Gavrilova, G̦., Riekstin̦š, A., Karpenskis, G., Narvils, M., Runce, A., Liguts, V., StAŠInSKIs, R., 2002. Latvāņi, to izplatības ierobežošana / Pagaidu rekomendācijas [Hogweed, bringing their spread under control / Provisional recommendations]. Ozolnieki: LLKC. 28 p.

LePeShKinA, L.A., 2019. K izucheniyu czenopopulyaczij Heracleum sosnowskyi Manden. v Botanicheskom sadu Voronezhskogo gosuniversiteta [To the study of populations of Heracleum sosnowskyi Manden. in the Botanical garden of Voronezh State University]. Ekosistemy. 20: 212-218.

Lukash, O.V., ZaVyalova, L.V., 2003. Heracleum mantegazzianum Sommier \& Levier (Apiaceae) na Chernihivskomu Polissi [Heracleum mantegazzianum Sommier et Levier (Apiaceae) in Chernihiv Polissya]. Ukrainskyi Botanichnyi Zhurnal, 60 (5): 561-566.

Luneva, N.N., 2014. Borshchevik Sosnovskogo v Rossiyskoy Federatsii [Sosnowsky's hogweed in The Russian Federation]. Protection and Plant Quarantine, 3: 12-18.

Mandenova, I.P., 1950. Kavkazskiye vidy roda Heracleum [Caucasian species of the genus Heracleum]. Monographs. Tbilisi, Georgia: Georgian Academy of Sciences. 104 p.

Marynych, O.M., Parkhomenko, H.O., Pashchenko, V.M., Petrenko, O.M., Shyshchenko, P.H., 2003. Fizyko-heohrafichne raionuvannia Ukrainy. Masshtab
1:4,000,000 [Physical-geographical zoning of Ukraine. Scale 1: 4,000,000]. Ukrainskyi Heohrafichnyi Zhurnal, 1: $16-22$.

Maslo, S., 2010. Giant hogweed Heracleum mantegazzianum Somier \& Levier - a new non-indigenous species in the flora of Bosnia and Herzegovina. Herbologia, 11 (2): 17-24.

McNeely, J.A., Mooney, H.A., Neville, L.E., Schei, P.J., WAAGE, J.K. (eds), 2001. Global strategy on invasive alien species. Cambridge, UK: IUCN in collaboration with the Global Invasive Species Programme.

Mežaka, A., Zvaigzne, A., TripĀne, E., 2016. Heracleum sosnowskyi Manden. monitoring in protected areas - a case study in Rēzekne municipality, Latvia. Acta Biologica Universitatis Daugavpiliensis, 16 (2): 181-189. Moravcová, L., Pyšek, P., Krinke, L., Müllerová, J., Pergloví, I., Pergl, J., 2018. Long-term survival in soil of seed of the invasive herbaceous plant Heracleum mantegazzianum. Preslia, 90 (3): 225-234.

Mosyakin, S.L., Fedoronchuk, M.M., 1999. Vascular plants of Ukraine: a nomenclatural checklist. Kyiv: M.G. Kholodny Institute Botany. 345 p.

Mucina, L., Bueltmann, H., Dierssen, K., Theurillat, J.-P., Raus, T., Čarni, A., Šumberová, K., Willner, W., Dengler, J., Gavilán, R., Chytrý, M., HáJek, M., Di Pietro, R., Iakushenko, D., Pallas, J., Daniëls, F., Bergmeier, E., Santos Guerra, A., Ermakov, N., TichÝ, L., 2016. Vegetation of Europe: hierarchical floristic classification system of vascular plant, bryophyte, lichen, and algal communities. Applied Vegetation Science, 19, Suppl. 1: 3-264. https://doi.org/10.1111/avsc.12257

MykhalyuK, I.M., Halahan, O.K., DuH, O.I., 2017. Ekobiolohichni zahrozy poshyrennia vydiv rodu Heracleum na terytorii mista Krementsia Ternopilskoi oblasti [Ecobiological threats of species distribution of the genus Heracleum on the territory of Kremenets, Ternopil region]. Ukrainian Journal of Ecology, 7 (4): 506-510. doi: 10.15421/2017_152.

Nielsen, C., Ravn, H.P., Nentwig, W., Wade, M., 2005. The giant hogweed best practice manual. Guidelines for the management and control of an invasive weed in Europe. Hørsholm, Denmark: Forest and Landscape Denmark. 44 p. OBoL̦EviČA, D., 2001. Latvānis un tā izplatības Latvijā [Hogweed and its distribution in Latvia]. [cit. 2021-03-5]. http://biodiv.daba.gov.lv/cooperation/lauksaimn/ fol514598

Oitsius, L.V., VolovyK, H.P., Doletskyi, S.P., Lysytsya, A.V., 2020. Distribution of adventive species Solidago canadensis, Phalacroloma annuum, Ambrosia artemisiifolia, Heracleum sosnowskyi in phytocenoses of Volyn' Polissya (Ukraine). Biosystems Diversity, 28 (4): 343-349. https://doi:10.15421/012043

Onyshchenko, V.A., Pryadko, O.I., Virchanko, V.M., Arap, R.Ya., Orlov, O.O., DatsiuK, V.V., 2016. Sudynni roslyny $i$ mokhopodibni natsionalnoho pryrodnoho parku «Holosiivskyi» [Vascular plants and bryophytes of Holosiivskyi national nature park]. Kyiv: Alterpress: 94 p.

Page, N.A., Wall, R.E., Darbyshire, S.J., Mulligan G.A., 2006. The biology of invasive alien plants in Canada. 4. Heracleum mantegazzianum Sommier \& Levier. Canadian Journal of Plant Science, 86: 569-589. https:// doi.org/10.4141/P05-158 
PanasenKo, N.N., 2017. On certain issues of biology and ecology of Sosnowsky's hogweed (Heracleum sosnowskyi Manden). Russian Journal of Biological Invasions, 8 (3): 272-281. https://doi.org/10.1134/S2075111717030110

Patocka, Jiri, Cupalova, K., 2017. Review article giant hogweed and photodermatitis. Military Medical Science Letters (Vojenské Zdravotnické Listy), 86: 1-4.

Pauková, Ž., Kapráloví, R., Hauptvogl, M., 2019. Mapping of occurrence and population dynamics of invasive plant species Heracleum mantegazzianum in the agricultural landscape. Journal of Central European Agriculture, 20 (2): 671-677.

Protopopova, V.V, Mosyakin, S.L., Shevera, M.V., 2002. Fitoinvazii $v$ Ukrainiyak zahroza bioriznomanittiu: suchasnyi stan i zavdannia na maibutnie [Plant invasions in Ukraine as a threat to biodiversity the present situation and tasks for the future]. Kyiv: M.G. Kholodny Institute of Botany of the National Academy of Sciences of Ukraine. 32 p.

Protopopova, V.V., Shevera, M.V., Mosyakin, S.L., 2006. Deliberate and unintentional introduction of invasive weeds: A case study of the alien flora of Ukraine. Euphytica, 148: 17-33. https://doi.org/10.1007/s10681006-5938-4

Puchalka, R., Rutkowski, L., OAna-Popa, M., Pliszko, A., PIWCZYNSKI, M., 2018. Bur-chervil Anthriscus caucalis M. Bieb. (Apiaceae) - potentially invasive species in forests. Baltic Forestry, 24 (2): 189-200.

PyseK, P., 1991. Heracleum mantegazzianum in the Czech Republic: dynamics of spreading from the historical perspective. Folia Geobotanica and Phytotaxonomica, 26 439-454.

R Core TEAm, 2020. R - a language and environment for statistical computing. Vienna: R Foundation for Statistical Computing. [cit. 2021-03-03]. https://www.R-project.org/.

Rabotnov, T.A., 1946. Opyt opredelenija vozrasta $\mathrm{u}$ travjanistyh rastenij [Practices on age determination in grass plants]. Botaničeskij Zhurnal, 31 (5): 24-28.

RAI, P.K., SINGH, J., 2020. Invasive alien plant species: their impact on environment, ecosystem services and human health. Ecological Indicators, 111: 106020. https://doi. org/10.1016/j.ecolind.2019.106020

Rajmis, S., Thiele, J., Marggraf, R., 2016. A cost-benefit analysis of controlling giant hogweed (Heracleum mantegazzianum) in Germany using a choice experiment approach. NeoBiota, 31: 19-41. https://doi.org/10.3897/ neobiota.31.8103

Reaser, J.K., Yeager, B.B., Phifer, P.R., Hancock, A.K., Gutierrez, A.T., 2003. Environmental diplomacy and the global movement of invasive alien species: a US perspective. In RuIz, G.M., CARLton, J.T. Invasive species: vectors and management strategies. Washington, DC, USA: Island Press, p. 362-381.

SAZYPEROVA, I.F., 1984. Borshheviki flory SSSR - novye kormovye rastenija [Heracleum species within flora of USSR - new fodder plants]. Leningrad: Nauka. 223 p.

Simpson, M., Prots, B., Vykhor, B., 2011. Modeling of the invasive plant distribution: case study of Sosnowski's hogweed Heracleum sosnowskyi Manden. in the Ukrainian Carpathian Mts. Journal of Biological Systems, 3 (1): 80-89.

SoBISZ, Z., 2007. Phytocenoses with Heracleum sosnowskyi Manden. in Central Pomerania. Roczniki Akademii Rolniczej v Poznaniu, Botanica Steciana, 11: 53-56.

Stukalyuk, S.V., Zhuravlev, V.V., Netsvetov, M.V., Kozyr M.S., 2019. Effect of invasive species of herbaceous plants and associated aphids (Hemiptera, Sternorrhyncha: Aphididae) on the structure of ant assemblages (Hymenoptera, Formicidae). Entmological Review, 99: 711-732. https://doi.org/10.1134/S0013873819060022

Tiley, G.E.D, Dodd, F.S., Wade, P.M., 1996. Heracleum mantegazzianum Sommier \& Levier. Journal of Ecology, 84: 297-319.

Tropicos.org. Missouri Botanical Garden, 2021. Genus profile Heracleum L. [cit. 2021-02-25]. http://www.tropicos.org/ name/Search?name=Heracleum

Tsiganov, D.N., 1983. Fitoindikacija jekologicheskih rezhimov $v$ podzone hvojno-shirokolistvennyh lesov [Phytoindication of environmental regimes in mixed coniferous and deciduous forests zone]. Nauka: Moscow. $197 \mathrm{p}$.

Tutin, T.G. (ed.) \& al., 1964-1994. Flora Europaea. Vol. 1-5. Cambridge: Cambridge University Press.

Vladimirov, V., Petrova, A., Barzov, Z., Gudžinskas, Z., 2019. The alien species of Heracleum (Apiaceae) in the Bulgarian flora revisited. Phytologia Balcanica, 25: 395405.

Vykhor, B., Prots B., 2012. Borshchivnyk Sosnovskoho (Heracleum sosnowskyi Manden.) na Zakarpatti: ekolohiia, poshyrennia ta vplyv na dovkillia [Sosnowsky's hogweed (Heracleum sosnowskyi Manden.) in the Transcarpathia: ecology, distribution and the impact on environment]. Studia Biologica, 6 (3): 185-196.

Westhoff, V., MaArel E., 1978. The Braun-Blanquet approach. In WhitTAKer, R.H. (ed.). Classification of plant communities. Hague: Dr. W. Junk, p. 287-399.

Received March 31, 2021 Accepted July 15, 2021 